\title{
Analisis Pengelolaan Dana Kapitasi JKN Pada Fasilitas Kesehatan Tingkat Pertama (FKTP) Di Kota Bitung
}

\author{
IMANUEL CHRISTIAN UNDAP ${ }^{1}$, LINTJE KALANGI ${ }^{2}$, HENDRIK MANOSSOH ${ }^{3}$
}

\author{
${ }^{1,2,3}$ Program Magister Akutansi, Fakultas Ekonomi dan Bisnis Universitas Sam Ratulangi \\ email : christianundap74@gmail.com ${ }^{1}$, lintjekalangi@yahoo.com ${ }^{2}$, hendrikmanossoh@yahoo.com ${ }^{3}$
}

\begin{abstract}
National Health Insurance (JKN) program in Indonesia was commenced in early 2014. JKN is organized by BPJS as regulated by law. To implement this, JKN Health Facilities role of First Instance (FKTP) belonging to the local government is, thus, very important. As compensation for this implementation, FKTP will then be paid by BPJS, known as capitation funds. Capitation Fund Financial Management in Bitung Municipality FKTP have encountered many problems implying the provision of health services. The purpose of this study is to analyze the financial management of local revenue capitation funds of JKN FKTP Bitung Government Municipality, including to identify the problems and solutions. JKN capitation funds are received from BPJS routinely and regularly received by FKTP. However, it is its management experiencing problems. This study is a qualitative exploratory research. The qualitative data were obtained by interviews, observation and documentation study, including a focus group discussion (FGD). Data validity and reliability were examined by triangulation. Data were then analysed by thematic analysis and interpreted to draw conclusions. The results show that the capitation fund management of JKN FKTP Bitung Government Municipality has not followed yet the regulation Therefore, the implications for the health service FKTP is not maximized for public. Other consequences that occur due to the condition of financial management according to regulations, has led to the very low capitation budget absorption of its programs and activities.
\end{abstract}

Keywords: National Insurance Health (JKN), FKTP, Capitation Fund

Abstrak. Jaminan Kesehatan Nasional (JKN) di Indonesia mulai berlaku pada tahun 2014 dan sesuai amanat undang - undang penyelenggara JKN adalah BPJS. Dalam pelaksanaan JKN ini peran Fasitas Kesehatan Tingkat Pertama (FKTP) milik pemerintah daerah sangat penting. Sebagai kompensasi dari pelaksanaan ini maka FKTP akan mendapatakan pembayaran dari BPJS yang dikenal dengan dana kapitasi. Pengelolaan Keuangan Dana Kapitasi di FKTP Pemerintah Kota Bitung menemui banyak hambatan yang berimplikasi pada penyerapan anggaran kegiatan FKTP dan penyediaan jasa pelayanan kesehatan oleh FKTP.Tujuan Penelitian ini untuk menganalisis pengelolaan keuangan pendapatan daerah dana kapitasi JKN FKTP Pemerintah Kota Bitung serta mengidentifikasi permasalahan yang terjadi dan solusi yang dapat diambil. Dana kapitasi JKN yang diterima dari BPJS secara rutin dan teratur diterima oleh FKTP akan tetapi dalam pengelolaannya ternyata mengalami kendala.Penelitian ini menggunakan metode analisis kualitatif eksploratif. Data kualitatif diperoleh dengan wawancara, observasi dan studi dokumentasi juga dengan focus group discussion (FGD) .Validitas dan reliabilitas data ditentukan dengan trianggulasi data untuk kemudian data yang diperoleh dilakukan analisa secara tematik serta intepretasi dalam rangka penarikan kesimpulan. Hasil penelitian menunjukan penganggaran dana kapitasi JKN oleh FKTP dilakukan dan tersentralisasi di Dinas Kesehatan sementara pelaksanaan pengelolaan dana kapitasi JKN FKTP Pemerintah Kota Bitung belum mengikuti regulasi yang mengatur, sehingga berimplikasi pada tidak maksimalnya pelayanan kesehatan FKTP pada masyarakat . Akibat lain yang terjadi karena kondisi pengelolaan keuangan yang tidak sesuai regulasi menyebabkan program dan kegiatan yang bersumber dari dana kapitasi JKN ini penyerapan anggaran sangat rendah.

Kata Kunci : Jaminan Kesehatan Nasional (JKN) , FKTP, Dana Kapitasi 


\section{Pendahuluan}

Tujuan pembangunan nasional sesuai dengan amanat undang - undang dasar 1945 adalah mencapai masyarakat adil dan makmur. Pembangunan nasional yang dimaksud adalah bukan hanya pembangunan fisik seperti infrastrukur gedung sekolah, rumah sakit dan bentuk fisik lainnya akan tetapi menyangkut juga pembangunan kualitas sumber daya manusia yaitu membangun dan menjamin kemampuan daya saing manusia atau warga negara akan tetapi keadilan yang merata untuk semua warga negara menikmati pelayanan kesehatan yang aman, bermutu dan terjangkau.

Menurut Mardiasmo ( 2002:74 ) salah satu paradigma tentang pembangunan kesehatan adalah "health for all" atau kesehatan untuk semua yang artinya adalah pelayanan kesehatan sebagai jasa public harus bisa diakses oleh seluruh lapisan masyarakat, tidak hanya lapisan masyarakat menengah keatas, sehingga menjadi kewajiban negara untuk menyediakan jasa publik tersebut. Hak warga negara untuk mendapatkan pelayanan kesehatan yang aman,bermutu dan terjangkau sudah diamanatkan oleh undang -undang dasar 1945 pasal 28 bagian h ayat 1 'Setiap orang berhak hidup sejahtera lahir dan batin bertempat tinggal dan mendapatkan lingkungan hidup yang baik dan sehat serta berhak memperoleh pelayanan kesehatan'.

Sistim jaminan sosial nasional pada dasarnya merupakan program negara yang bertujuan memberi kepastian perlindungan dan kesejahtraan sosial bagi seluruh rakyat Indonesia. Melalui program ini setiap penduduk diharapkan dapat memenuhi kebutuhan dasar hidup yang layak apabila terjadi hal - hal yang dapat mengakibatkan hilang atau berkurangnya pendapatan termasuk pada saat mengalami gangguan kesehatan (Bastian, 2015:40).

Dana kapitasi JKN adalah dana yang dibayarkan secara berkala oleh BPJS Kesehatan kepada puskesmas yang merupakan penyelenggara pelayanan kesehatan atau sebagai salah satu fasilitas bagi peserta JKN. Sumber dana kapitasi berasal dari hasil pengelolaan dan pengembangan dana iuran peserta JKN. Pembayaran Dana kapitasi JKN dilakukan dimuka setiap bulan tanpa memperhitungkan banyaknya pasien peserta JKN yang berobat dan jenis pelayanan kesehatan yang diberikan oleh puskesmas. Dari dana kapitasi inilah pemerintah daerah, melalui puskesmas, memperoleh dana untuk pelayanan kesehatan kepada pasien peserta program JKN. Bagi Puskesmas ini artinya setiap bulan mereka akan mendapatkan transferan tetap dana segar yang dalam setahun jumlahnya sangat besar dimana dana tersebut merupakan hak Puskemas dan secara regulasi diberikan kemudahan dalam pengelolaanya.

Data Komposisi total anggaran yang dikelola oleh FKTP (Puskesmas) Kota Bitung dari berbagai sumber anggaran menggambarkan kontribusi dana kapitasi JKN 61\%, Dana BOK $15 \%$ dan APBD Kota Bitung $24 \%$. Dari informasi ini dapat dilihat bahwa anggaran untuk kegiatan FKTP yang bersumber dari dana kapitasi JKN secara jumlah lebih besar dari dana lewat APBD puskesmas dan Bantuan Oprasional Kesehatan (DAK Kesehatan).

Sebagai Unit pelaksana teknis dibawah Dinas Kesehatan maka pelaksanaan kegiatan dan anggaran Puskesmas adalah bersumber dari Anggaran Pendapatan dan Belanja Daerah (APBD ) Kota Bitung. Sehingga untuk setiap FKTP dalam kegiatan pelaksanaan Anggaran Pendapatan dan Belanja Daerah mereka bertanggungjawab untuk pelaksanaan anggarannya.FKTP yang merupakan bagian dari organisasi pemerintah daerah (OPD) maka sudah menjadi keharusan bahwa pengelolaan keuangan yang ada dalam puskesmas akan mengikuti dan tunduk pada azaz - azaz pengelolaan keuangan daerah begitu juga dalam pengelolaan dana kapitasi JKN, sementara dilain pihak pengelolaan dana kapitasi JKN mendapatkan kemudahan dalam penggunaannya melalui Perprrs 32 Tahun 2014. 
Pengelolaan dana kapitasi JKN di Kota Bitung mengalami hambatan lewat penyerapan anggaran program dan kegiatan yang bersumber dari dana kapitasi JKN FKTP Kota Bitung sangat rendah terlebih khusus untuk program kegiatan pengadaan obat dan alat kesehatan meskipun penerimaan dana kapitasi JKN dari BPJS tepat waktu. Anggaran kegiatan FKTP yang bersumber dari kapitasi JKN untuk tahun anggaran 2016 dengan realisasi per tanggal 30 November 201647 \% . Dari total anggaran tersebut peruntukan khusus untuk belanja pengadaan dan alat kesehatan masih $0 \%$, dimana dua hal tersebut merupakan kebutuhan oprasional yang paling "urgent" bagi FKTP untuk maksimalisasi pelayanan kesehatan terhadap masyarakat.Selain itu persentase tingkat rujukan ke rumah sakit oleh FKTP Kota Bitung sampai bulan Oktober adalah rata-rata $16.79 \%$, dan jika dibandingkan dengan persentase ideal rujukan FKTP menurut BPJS Kesehatan idealnya tidak lebih dari10\%. Jumlah rujukan FKTP Kota Bitung dapat dilihat dalam tabel 1

Tabel 1

Persentase Rujukan FKTP Kota Bitung

\begin{tabular}{|l|c|c|c|}
\hline NAMA FKTP & $\begin{array}{c}\text { TOTAL S.D } \\
\text { BULAN } \\
\text { OKTOBER }\end{array}$ & $\begin{array}{c}\text { JLH } \\
\text { BULAN }\end{array}$ & $\begin{array}{c}\text { \% / } \\
\text { BULAN }\end{array}$ \\
\hline $\begin{array}{l}\text { BITUNG } \\
\text { BARAT }\end{array}$ & 96.8 & 10 & 9.68 \\
\hline GIRIAN WERU & 201.8 & 10 & 20.18 \\
\hline AERTEMBAGA & 212.5 & 10 & 21.25 \\
\hline TINOMBALA & 186.6 & 10 & 18.66 \\
\hline DANOWUDU & 184.2 & 10 & 18.42 \\
\hline PAPUSUNGAN & 202.1 & 10 & 20.21 \\
\hline PACEDA & 177.7 & 10 & 17.77 \\
\hline SAGERAT & 200.7 & 10 & 20.07 \\
\hline PINTU KOTA & 48.9 & 10 & 4.89 \\
\hline TOTAL & & 151.14 \\
\hline JUMLAH FKTP & & \\
\hline RATA - RATA & & & $\mathbf{1 6 . 7 9 \%}$ \\
\hline
\end{tabular}

Berdasarkan uraian tersebut penelitian ini dilakukan dengan tujuan adalah untuk menganalisa proses penganggaran, pelaksanaan dan penatausahaan serta pemanfaatan dana kapitasi JKN FKTP Kota Bitung.

\section{Model Analisis}

Model analisis ini adalah dengan melakukan pemahaman regulasi Perpres 32 Tahun 2014 tentang pengelolaan keuangan dana kapitasi JKN disinkronisasikan dengan Permendagri 13 Tahun 2006 mengenai azaz pengelolaan keuangan daerah. Gambar 1 


\section{Gambar 1}

Model Analisis

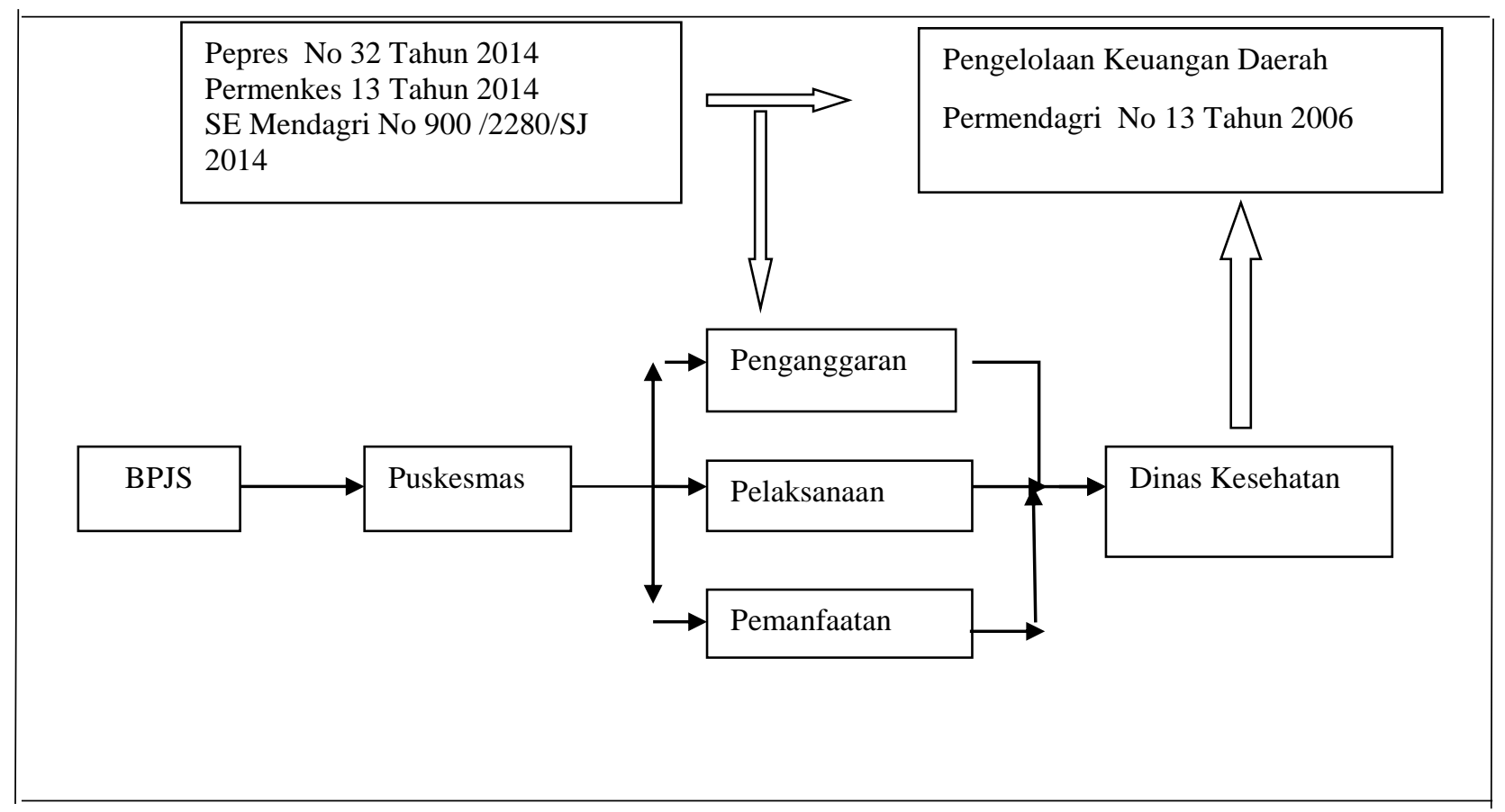

Sumber : Data Olahan (2016)

\section{Metode Penelitian}

Penelitian ini menggunakan metode penelitian kualitatif dengan pendekatan eksploratori (exploratory approach). Pendekatan eksploratori dalam penelitian kualitatif adalah cara kerja penelitian yang dimaksudkan untuk menemukan lebih jauh dan mendalam terhadap kemungkinan-kemungkinan lain dari permasalahan yang diteliti (Ibrahim 2015:64).

Teknik pengumpulan data yang ditempuh dalam penelitian ini adalah melalui pengamatan/observasi (observation), wawancara mendalam (indepth interview), dan dokumentasi (documentation). Selanjutnya, uji keabsahan data dalam penelitian kualitatif meliputi uji credibility (validitas internal), transferability (validitas eksternal), dependability (reliabilitas) dan confirmability (objektivitas).Wawancara dilakukan kepada 7 orang Kepala FKTP , 9 orang Bendahara FKTP, Kasubag Keuangan Dinas Kesehatan, Kasubid Jamkesmas, Bendahara Penerimaan Dinas Kesehatan, Kasubag Perencanaan Dinas Kesehatan, Pejabat Pembuat Komitment (PPKom) dan Kepala Cabang BPJS Kota Bitung.

Aktivitas analisis data Miles and Hubeman dalam Sugiyono (2015:120) terdiri atas: data reduction, data display dan conclusion drawing/verification yang dilakukan secara interaktif dan berlangsung secara terus menerus sampai tuntas, sehingga datanya mencapai jenuh.

\section{Analisis dan Pembahasan}

Penelitian ini dilakukan selama 3 (tiga) bulan yakni antara bulan Oktober 2016 hingga bulan Desember 2016. Instrumen penelitian pendukung adalah pedoman wawancara, instrumen observasi lapangan, alat perekam berupa audio recorder untuk merekam pelaksanaan wawancara dengan informan yang hasilnya menjadi transkrip data. 


\section{Kepesertaan JKN Kota Bitung}

Jumlah peserta jaminan kesehatan nasional di Kota Bitung dapat dilihat dalam gambar 2 berikut ini:

Gambar 2

Kepesertaan JKN

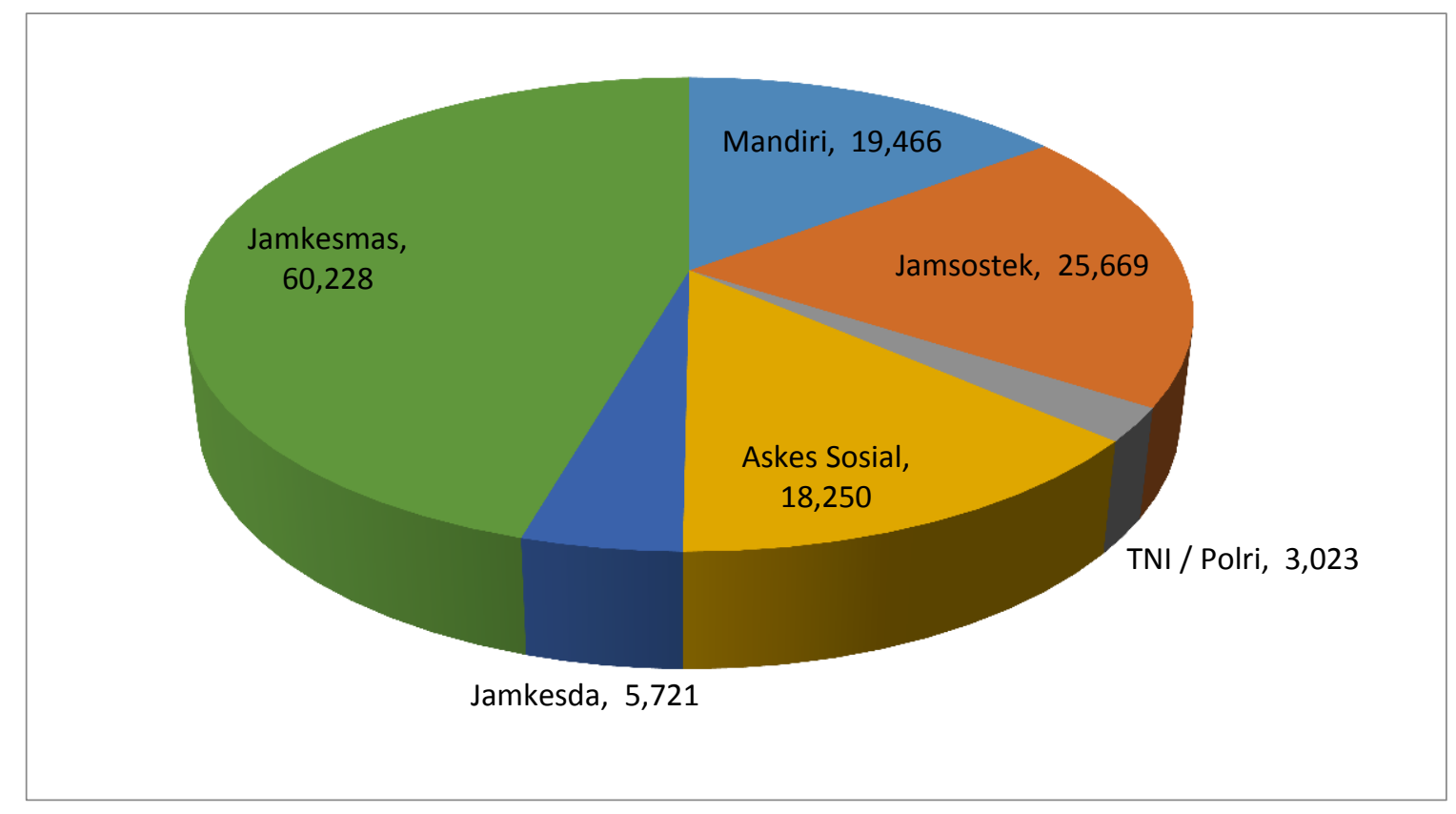

Sumber : BPJS (2016)

Sementara jumlah fasilitas kesehatan dan dokter yang bekerjasama dengan BPJS untuk pelayanan JKN di Kota Bitung baik fasilitas kesehatan milik pemerintah dan swasta sebagai berikut :

1. Puskesmas 9 Unit

2. Praktik Dokter 128 Orang

3. Praktik Dokter Gigi 8 Orang

4. Klinik Pratama 6 Unit

5. Rumah Sakit Umum 3 Unit

\section{Penganggaran Dana Kapitasi JKN}

Perpres 32 Tahun 2014 bagian kedua mengatur mengenai penganggaran pada pasal 4 ayat (3): rencana pendapatan dan belanja dana kapitasi JKN sebagaimana dimaksud dianggarkan dalam RKA Dinas Kesehatan. Dalam wawancara dengan Bendahara serta kepala FKTP untuk tahap penganggaran mengikuti regulasi yang mengatur dan untuk teknik penganggaran FKTP mempunyai metode sendiri. Salah satu kutipan wawancara:

"Mekanisme penganggaran mulai dari rka kami buat contoh untuk tahun depan tahun ini RKA yang kami buat RKAnya dari kita, kita pake estimasi dari jumlah peserta yang sekarang kita tambah $2 \%$ tiap bulan karena kami nda tau pasti to seberapa jumlah peserta tiap bulan berapa jumlah kapitasi yang kami terima karena tiap bulan pasti beda-beda jadi itu kami susun rka tambah estimasi 2\% per bulan untuk jumlah peserta jadi dikalikan 6 ribu per peserta kan dana kapitasi untuk paceda kan 6 ribu per peserta dapat dia pe nominal berapa 
torang bagi $70 \%$ jasa $30 \%$ dukungan oprasional yang kami pake atk,bbm ada belanja modal , obat , bhp , alkes .."

Teknik penganggaran dengan estimasi merupakan satu cara praktis yang dipilih disebabkan Karena jumlah penerimaan dana kapitasi JKN dari BPJS tidak dapat diprediksi jumlahnya. Ketidakpastian jumlah penerimaan tersebut disebabkan karena dana kapitasi dibayarkan berdasarkan kepesertaan berdasarkan lokasi FKTP dimana mutasi peserta JKN tidak dapat diprediksi tiap bulan.

Teknik yang digunakan dalam penganggaran kesehatan salah satunya adalah teknik incremental budgeting. Incremental Budgeting adalah sistim anggaran belanja dan pendapatan yang memungkinkan revisi selama tahun berjalan sekaligus dasar penentuan usulan anggaran periode tahun yang akan datang. Angka dipos pengeluaran kesehatan merupakan perubahan (kenaikan) dari angka periode sebelumnya. Permasalahan yang harus diputuskan bersama adalah metode penaikan / penurunan (incremental) dari angka kesehatan tahun sebelumnya (Bastian, 2015:403). Keunggulan dan kelemahan Sistim Penganggaran Kesehatan Incremental Budgeting dapat dilihat dalam table 1.

Tabel 1

\section{Keunggulan dan Kelemahan Sistim Penganggaran Kesehatan Incremental Budgeting}

\begin{tabular}{|l|l|}
\hline Keunggulan & Kelemahan \\
\hline $\begin{array}{l}\text { 1. Mengatasi rumitnya proses } \\
\text { penyusunan anggaran kesehatan }\end{array}$ & $\begin{array}{l}\text { 1.Perhatian terhadap laporan } \\
\text { pelaksanaan anggaran penerimaan dan } \\
\text { pengeluaran kesehatan sangat sedikit. }\end{array}$ \\
\hline $\begin{array}{l}\text { 2. Tidak memerlukan pengetahuan yang } \\
\text { terlalu rumit untuk memahami } \\
\text { program baru }\end{array}$ & $\begin{array}{l}\text { 2.Diabaikannya pencapaian prestasi } \\
\text { kesehatan, realisasi penerimaan dan } \\
\text { pengeluaran kesehatan yang dianggarkan }\end{array}$ \\
\hline 3. Dapat mengurangi konflik & $\begin{array}{l}\text { 3.Para penyusun anggaran kesehatan, } \\
\text { tidak memiliki alasan rasional dalam } \\
\text { menetapkan target penerimaan dan } \\
\text { pengeluaran kesehatan }\end{array}$ \\
\hline
\end{tabular}

Sumber : Bastian (2015)

\section{Pelaksanaan dan Penatausahaan Dana Kapitasi JKN}

Pelaksanaan jaminan kesehatan nasional di kota Bitung dilaksanakan oleh BPJS sebagai pelaksana Sistim Jaminan Kesehatan Nasional (SJKN) dengan Dinas Kesehatan Kota Bitung melalui perjanjian kerja sama Nomor 697/KTR/X-01/2015 dan Nomor 440/KES/1100/XII/2015 tanggal 21 Desember 2015. Dalam perjanjian tersebut pasal 4 ayat c menyebutkan membayar biaya kapitasi kepada pihak kedua paling lambat tanggal 15 (lima belas) bulan berjalan.Dana kapitasi yang dibayarkan ke FKTP merupakan pendapatan daerah dan merupakan hak FKTP.

Dari wawancara yang dilakukan kepada kepala FKTP dan Bendahara penerimaan dana kapitasi JKN oleh FKTP tidak mengalami keterlambatan kalaupun ada keterlambatan maka itu diinformasikan oleh BPJS. Kutipan wawancara dengan kepala BPJS:

"Tanggal 15 ada beberapa sempat tertunda karena ada rekonsiliasi data ada kelebihan pembayaran tapi itu sudah diberitahukan bahwa akan ada penundaan......"

Kewajiban dari BPJS yang tepat waktu dalam melaksanakan kewajibannya menunjukan komitment yang baik dalam pelaksanaan SJSN di Kota Bitung. 
Selain komitment hal lainnnya yang penting adalah mekanisme implementasi program yang sudah ditetapkan melalui standart operating procedure (SOP) dan dicantumkan dalam guideline program kebijakan. SOP yang baik mencantumkan kerangka kerja yang jelas sistematis, tidak berbelit dan mudah dipahami oleh siapapun karena akan menjadi acuan dalam bekerjanya implementor.Struktur organisasi pelaksana pun sejauh mungkin menghindari hal berbelit, panjang dan kompleks.Struktur organisasi pelaksana harus dapat menjamin adanya pegambilan keputusan atas kejadian luar biasa dalam program secara cepat. Dan hal ini hanya dapat lahir jika struktur didesain secara ringkas dan fleksibel menghindari "virus weberian" yang kaku dan terlalu panjang (Mulyadi, 2015:29).

Dalam pengelolaan keuangan pendapatan daerah dana kapitasi JKN secara umum standart of procedure berdasarkan perpes 32 Tahun 2014 digambarkan sebagai berikut dalam gambar 3

Gambar 3

Alur Mekanisme Pengelolaan Dana Kapitasi JKN Pepres 32 Tahun 2014

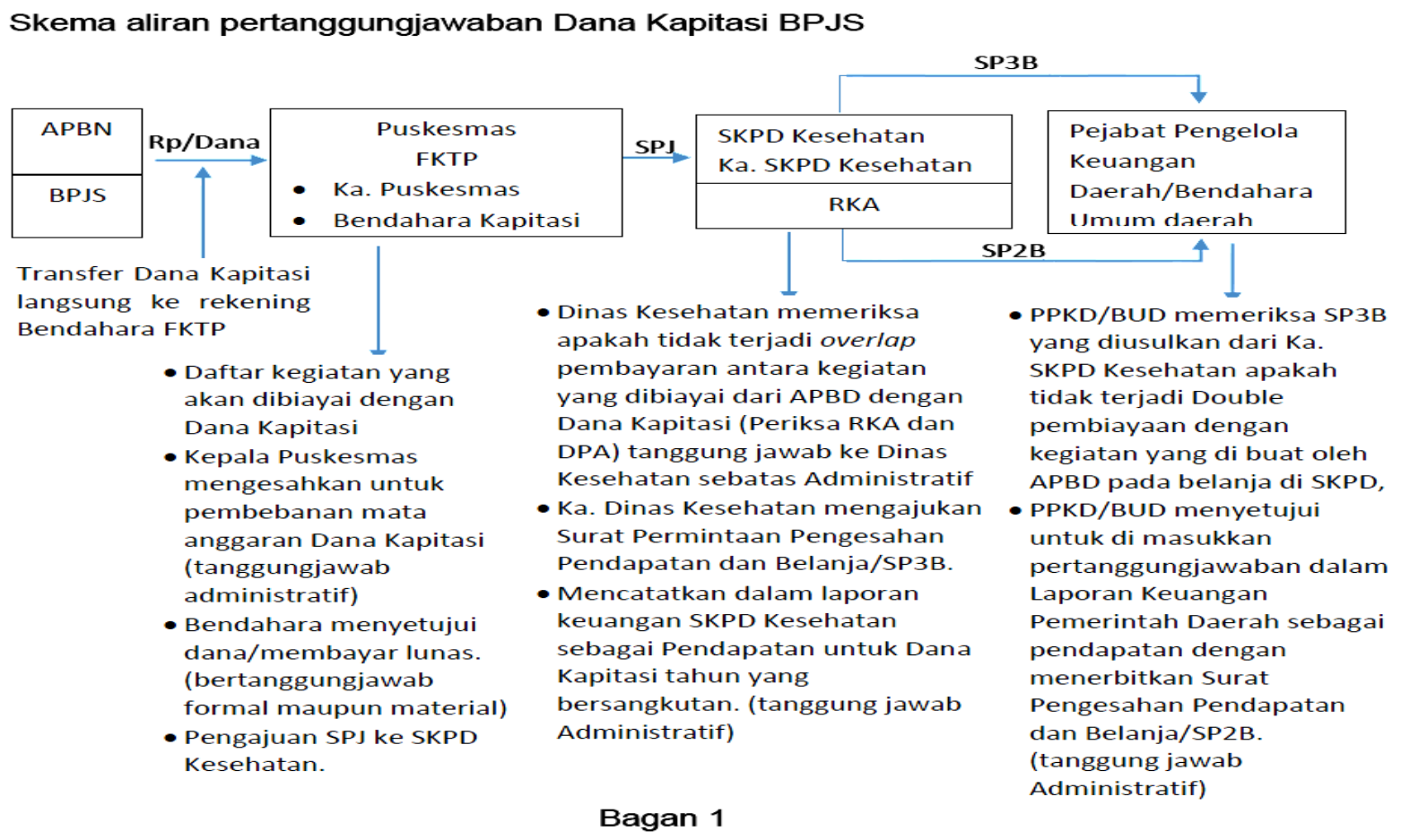

Sumber : BPPKP Kemenkeu (2014)

Pelaksanaan dana kapitasi JKN FKTP Kota Bitung dari hasil wawancara seperti contoh informasi dari seorang bendahara FKTP :

"Torang terima dari BNI tanggal 15 torang cek rekening laeng kali kan ada doi maso jadi langsung torang transfer ke kas daerah .... langsung ke kas daerah , dari transfer daerah bukti transfer torang kase ke bendahara penerimaan dinas Kesehatan...kemudian baru diklaim setelah diklaim baru torang ambe di bendahara pengeluaran jadi taputar - taputar ..."

Dari semua informan yang diwawancarai memberikan informasi yang sama .Dari informasi ini dapat dianalisa bahwa dana kapitasi JKN oleh FKTP disetorkan ke Kas Daerah sesuai dengan regulasi Permendari 13 Tahun 2006 sementara oleh Perpres 32 ahun 2014 tidak mengatur seperti itu. Setoran pendapatan daerah dana kapitasi JKN ke Kas Daerah tidak diatur dalam regulasi pengelolaan dana kapitasi JKN. Peraturan Presiden No 32 Tahun 
2014 Pasal 7 poin (2) Pendapatan sebagaimana dimaksud pada poin (1) digunakan langsung untuk pelayanan kesehatan peserta JKN pada FKTP. Jika dianalisa maka hal yang dipraktikkan oleh FKTP di Kota Bitung adalah penggunaan tidak langsung.

Implikasi dari proses pengelolaan yang panjang ini kemudian menyebabkan penyerapan anggaran dana kapitasi JKN oleh FKTP sangat rendah untuk realisasi jasa pelayanan rata-rata realisasi $50 \%$ selain itu belanja Obat-obatan,Alat Kesehatan semua FKTP masih $0 \%$ per bulan November saat wawancara dilakukan.

Selain permasalahan diatas faktor pemahaman akan regulasi juga menjadi faktor penghambat dalam pelaksanaan pengelolaan dana kapitasi JKN. Dalam pelaksanaan pengelolaan dana kapitasi di FKTP Kota Bitung setelah dilakukan penelitian dengan wawancara ternyata implementasi regulasi dalam pelaksanaannya belum dipahami dan tersosialisasi dengan baik.Van Meter dan Van Horn dalam Mulyadi (2015:72) dalam berbagai kasus implementasi sebuah program terkadang perlu didukung dan dikoordinasikan dengan instansi lain agar tercapai keberhasilan yang diinginkan.

Selain itu faktor lain yang menyebabkan rendahnya penyerapan anggaran adalah:

1. Proses pencairan anggaran tersentralisasi di Dinas Kesehatan sehingga memerlukan waktu proses yang panjang.

2. Anggaran dana kapitasi JKN di peruntukkan untuk FKTP meskipun dianggaran dalam DPA Dinas Kesehatan, sementara dalam proses pencairan anggaran bagian Keuangan Dinas Kesehatan juga mengelola anggaran dari Dinas Kesehatan sendiri.

3. Dalam pencairan anggaran dana kapitasi JKN memerlukan kelengkapan administrasi yang dalam beberapa kasus tidak dipersiapkan sehingga dokumen pertanggungjawaban ditolak oleh bagian Keuangan DPPKAD.

4. Dalam perencanaan anggaran kas (SPD) FKTP tidak dilibatkan dan tidak diinformasikan sehingga dalam proses pencairan keuangan dana kapitasi FKTP tidak mengetahui periode waktu ketersedian anggaran .

5. Pengadaan Alat Kesehatan dan Obat - obatan terhambat pada kebijakan pengadaan barang dan jasa yang dipersyaratkan yaitu melalui pengadaan secara E Catalogue .

Penatausahaan dana kapitasi JKN FKTP karena mengikuti regulasi pengelolaan keuangan daerah Permendagri 13 Tahun 2006 maka penatausahaan juga tersentralisasi di Dinas Kesehatan sementara untuk FKTP hanya pembukuan sederhana

\section{Pemanfaatan Dana Kapitasi JKN}

Penggunaan dana kapitasi JKN diatur oleh Permenkes untuk kemudian diatur oleh surat keputusan kepala daerah sesuai dengan bunyi pasal 3 point 4 Permekes 19 Tahun 2014 : Besaran alokasi sebagaimana dimaksud ditetapkan setiap tahun dengan keputusan kepala daerah atas usulan kepala SKPD Dinas Kesehatan Kabupaten / Kota dengan mempertimbangkan :

a. Kebutuhan obat,alat kesehatan dan bahan medis habis pakai.

b. Kegiatan oprasional pelayanan kesehatan dalam rangka mencapai target kinerja dibidang upaya kesehatan perorangan dan

c. Besar tunjangan yang telah diterima dari pemerintah daerah.

Pemanfaatan dana kapitasi JKN oleh FKTP Kota Bitung menggunakan dasar Keputusan Walikota No 188.45/HKM/SK/123/2014 mengenai alokasi dana kapitasi JKN Pada Puskesmas Kota Bitung dengan pembagian 70\% untuk jasa dan 30\% Obat,Alkes,BHP dan hal ini dimungkinkan oleh Permenkes No 19 Tahun 2014 Pasal 3 Ayat 4.

Hal lain yang terjadi adalah para pengelola dana kapitasi JKN FKTP sangat memahami regulasi yang khusus mengatur tentang pemanfaatan dana kapitasi sementara regulasi lain yang berhubungan dengan pengelolaan dana kapitasi JKN yaitu Perpres 32 Tahun 2014 dan 
SE Mendagri 900/2280/SJ tanggal 5 Mei 2014 tidak di pahami. Van Meter dan Van Horn dalam Mulyadi (2015:72) variabel yang mempengaruhi kinerja implementasi salah satunya adalah sikap implementor yang mencakup tiga hal yang penting yaitu respons implementor terhadap kebijakan yang akan mempengaruhi kemauannya untuk melaksanakan kebijakan, kognisi yang merupakan pemahamannya terhadapan kebijakan dan preferensi nilai yang dimiliki oleh implementor.

\section{Penutup}

1. Proses pelaksanaan penganggaran untuk dana kapitasi JKN FKTP Kota Bitung dilaksanakan tersentralisasi di Dinas Kesehatan dan masuk dalam DPA Dinas Kesehatan bersama - sama dengan anggaran kegiatan Dinas Kesehatan. Fungsi FKTP hanya membuat dan menyiapkan RKA dan dalam proses pelaksanaan kegiatan dari anggaran tersebut semuanya dilaksanakan oleh Dinas Kesehatan. Sentralisasi penganggaran FKTP tersebut merupakan amanat dari regulasi yang mengatur tentang pengelolaan dana kapitasi JKN oleh FKTP yaitu Perpres 32 Tahun 2014.

2. Pelaksanaan Pengelolaan Pendapatan Daerah dana kapitasi JKN yang dikelola oleh Fasilitas Kesehatan Tingkat Pertama ( FKTP) Pemerintah Kota Bitung dilaksanakan dengan mengacu pada regulasi yang mengatur mengenai pengelolaan keuangan daerah yaitu Permendagri 13 Tahun 2006 dan perubahan - perubahannya, dimana proses pengelolaan dana kapitasi JKN dilaksanakan masih tidak langsung yaitu dengan prosedur pengelolaan keuangan daerah yang umumnya berlaku melalui proses penerbitan SPP, SPM dan SP2D dari kas daerah .

3. Penyerapan anggaran untuk program dan kegiatan yang bersumber dari dana Kapitasi JKN sangat rendah disebabkan karena dalam pengelolaan dana kapitasi FKTP Pemerintah Kota Bitung tidak mengacu pada Perpres 32 Tahun 2014 yang khusus mengatur tentang pengelolaan dana kapitasi JKN. Selain itu proses pengadaan Alat Kesehatan dan Obat - obatan yang dilaksanakan melalui Dinas Kesehatan terhambat karena harus melalui mekanisme pengadaan e catalogue.

4. Pemahaman regulasi dari para pengelola dana kapitasi JKN ini baik sebagai Kepala FKTP maupun Bendahara sangat rendah yang berakibat pada koordinasi dengan intansi lain yang merupakan penanggungjawab keuangan daerah dalam hal ini Pejabat Pengelola Keuangan Daerah (PPKD) tidak berjalan dengan baik. Kurangnya pemahaman terhadap regulasi oleh para pengelola dana kapitasi JKN ini menimbulkan ketidakyakinan pada saat melaksanakan komunikasi dengan PPKD dalam memberikan pemahaman yang benar mengenai proses pengelolaan dana kapitasi JKN.

Saran yang dapat diberikan adalah:

1. Pengelolaan Dana Kapitasi JKN sebaiknya mengikuti regulasi yang mengatur itu yaitu Perpres No 32 Tahun 2014 dan SE Mendagri 900 /2280/SJ tanggal 5 Mei 2014. Pada prinsipnya regulasi yang dibuat sudah melalui berbagai pertimbangan dengan tidak membenturkan regulasi tersebut dengan regulasi - regulasi lain yang dikeluarkan oleh pemerintah sehingga keraguan dalam impelementasi regulasi tersebut harusnya tidak terjadi. Sinkronisasi antara Pepres No 32 Tahun 2014 dengan Permendagri 13 tahun 2004 pada prinsipnya dapat dilakukan. Untuk mengatasi keraguan tersebut perlu melakukan pembandingan proses pengelolaan dana kapitasi di daerah lain sebagai acuan untuk dapat dijadikan yurisprudensi dalam pelaksanaan pengelolaan dana kapitasi JKN di Kota Bitung. 
2. Pengelola Dana Kapitasi JKN di FKTP serta Kepala FKTP harus meningkatkan pemahaman mengenai regulasi yang mengatur Dana Kapitasi JKN . Pertemuan yang bersifat sosialisasi yang dilaksanakan oleh Dinas Kesehatan maupun oleh BPJS dapat dimanfaatkan dengan memberikan informasi tentang pengelolaan dana kapitasi JKN dengan turut mengikutsertakan PPKD sehingga dapat diperoleh pemahaman yang sama dalam pelaksanaannya.

3. Dinas Kesehatan sebagai atasan langsung dari FKTP dalam pengelolaan Pendapatan Daerah dana kapitasi JKN, yang fungsinya sebagai pelaksana proses pencairan anggaran FKTP dalam proses perencanaan anggaran kas harus dapat melibatkan FKTP sehingga dengan keterlibatan FKTP sinkronisasi kegiatan dengan kebutuhan pendanaan akan tepat waktu dan penyerapan anggaran akan sesuai kebutuhan dan tidak terlambat.

\section{Daftar Pustaka}

Abidin, Said Zainal (2004)" Kebijakan Publik" . Jakarta : Salemba.

Bungin , Burhan ( 2011) "Penelitian Kualitatif" . Jakarta : Prenada Media Group

Bastian, Indra ( 2015 )" Akuntansi Kesehatan".Jakarta : Erlangga.

Dye ,Thomas R ( 1992 ) " Understanding Public Policy". New Jersey : Prentice Hall

Edward III,George (1980) " Implementing Public Policy " Washington Congressional Quaterly,Inc.

Freeman, Robert J. dan Draig D Shoulders (2003) " Governmental and Non Profit Accounting Theory and Practise". Pearson Education

Hughes , Owen (1994) ." Public Management and Administration an introduction ". London : The Macmillan Press LTD

Ibrahim (2015). " Metodologi Penelitian Kualitatif". E Book Pontianak .

James H. Davis, F. David Scoorman dan Lex Donalson (1997). "Toward a Stewardship Theory of Management." Academy of Management Review Vol. 22, No. 1, page 2247.

Jones, Pendlebury (1988)." Public Sector Accounting "London . Pitman Publishing

Kuncoro, Mudrajad ( 2009 ) , " Metode Riset Untuk Bisnis dan Ekonomi " Jakarta : Erlangga

Mamelo ,Gresly (2016), " Analisis Pelaksanaan dan Penatausahaan Dana Desa Di Kecamatan Kotamobagu Timur" Tesis ,Manado ,FE Unsrat.

Mardiasmo (2002) "Akuntansi Sektor Publik" .Yogyakarta : Andi

Mardiasmo (2002)" Otonomi dan Manajemen Keuangan Daerah ". Yogyakarta Andi

Mboi, Nafsiah (2015), "Indonesia : On The Way to Universal Health Care"

Health and System Reform Journal Vol 1 (2015) No 2.

Marshal, Catherine dan Gretchen Rossman (1995). "Designing Qualitative Research " , Second Edition .London : Sage Publication

Mulyadi, Deddy (2015) , "Studi Kebijakan Publik dan Pelayanan Publik", Bandung :Penerbit Alfabeta.

Myers, Margaret (2000), "Qualitative Research and The Generalizability Question: Standing Firm with Proteus" The Qualitative Report (Vol. 4 Num. 3/4).

Nordiawan, Deddi dan Hertianti Ayuningtyas ( 2010 ) . " Akuntansi Sektor Publik " Jakarta : Salemba Empat

Pisani, Elisabet, et all (2015) "Indonesia Road To Universal Coverage a Political Journey ",Health And Political Journal Oxford (2016)

Santoso (2011), "Efisiensi dan Efektifitas Pengelolaan Keuangan Daerah di Kabupaten Ngawi", Tesis. Surakarta : FE-Universitas Sebelas Maret.

Satori Djam'an et. al (2013), "Metodologi Penelitian Kualitatif". Bandung : CV. Alfabeta

Standar Akuntansi Keuangan (2007) ), Ikatan Akuntan Indonesia.Jakarta 
Suardi (2016), "Factors Affecting JKN Capitation Fund Manager Performance in Work

Environment FKTP Merauke District Health Office ", International Journal of Sciences:

Basic and Applied Research (2016) Vol 30 No 4 : 66-83

Sujarweni Wiratna (2015), "Akuntansi Sektor Publik". Yogyakarta : Pustaka Baru Press

Sugiyono (2015), Memahami Penelitian Kualitatif. Bandung : Penerbit Alfabeta

Trisnantoro, Laksono (2015) Provider Payment Mechanism Change after The Implementation Of Universal Coverage Policy In Indonesia Journal Of Public Health Medicine Vol 15 No 1.

The, Ivy (2015), "Universal Health Coverage In Indonesia One Year On" . The Economist Intelegence Unit Journal ( 2015).

Wildavsky, Aaron ( 2001) . "Budgeting and Governing". New Jersey: Transaction Publishers 